\title{
Development of Bicycle Shift Models in Universiti Kebangsaan Malaysia Campus
}

\author{
(Pembangunan Model Anjakan Berbasikal di Kampus \\ Universiti Kebangsaan Malaysia) \\ Amiruddin Ismail \& Shazrizil Zakaria*
}

\begin{abstract}
Cycling is suitable for short trips and take shorter commute time for students who are living in the campus. Moreover, it requires lower costs and can reduce environmental pollution. However, cycling in campus is not well received by the students. This is due to certain factors such as hilly terrain, uncertain weather, and also the exposure to road traffic accidents. A survey had been conducted in UKM Bangi campus to identify the factors that can influence students to choose cycling as the main choice of transport. Surveys were targeted to 170 respondents from the students in the campus. Two bicycle shift models were developed based on travel distance of non-hilly terrain and travel distance if covered lane provided. $76.5 \%$ of the respondent agreed that hilly terrain makes bicycle is not an option inside campus while 79.4\% believe that the weather condition makes them not to choose bicycle. From both model, it is seen that the probability to shift to bicycle is increased as the travel distance increases if the terrain is not hilly and if there is covered lane provided. Overall, the study is a success and might be useful for future research on sustainable transportation system in campus.
\end{abstract}

Keywords: Bicycle modal shift; sustainable transportation system

ABSTRAK

Mod berbasikal adalah sesuai untuk perjalanan jarak dekat dan mengambil masa yang singkat bagi pengguna yang tertumpu di dalam kawasan kampus. Selain itu, ia tidak menelan kos yang banyak dan berupaya mengurangkan pencemaran alam sekitar. Namun demikian, penggunaan basikal di kawasan kampus tidak mendapat sambutan yang menggalakkan. Hal ini adalah disebabkan faktor-faktor tertentu seperti bentuk muka bumi yang berbukit-bukau, keadaan cuaca, dan juga risiko terdedah dengan kemalangan jalan raya. Satu kajian soal selidik telah dijalankan di kampus UKM Bangi untuk mengenalpasti faktor yang boleh mempengaruhi pilihan berbasikal di kampus. Soal selidik disasarkan kepada 170 pelajar di dalam kampus. Dua buah model anjakan berbasikal telah dibangunkan berdasarkan jarak perjalanan laluan tidak berbukit dan jarak perjalanan jika laluan berbumbung disediakan. 76.5\% responden bersetuju bahawa bentuk muka bumi yang berbukit menghalang mereka memilih basikal manakala $79.4 \%$ responden pula percaya bahawa cuaca yang tidak menentu juga menyebabkan mereka tidak memilih berbasikal. Daripada kedua-dua model yang dihasilkan, kebarangkalian untuk beranjak kepada berbasikal meningkat pada jarak yang semakin meningkat. Secara keseluruhannya, kajian ini telah mencapai objektifnya dan berguna untuk kajian sistem pengangkutan lestari kampus pada masa akan datang.

Kata kunci: Mod anjakan berbasikal; sistem pengangkutan lestari

\section{INTRODUCTION}

Sustainable development is important to ensure the holistic welfare of society. This situation is not sake only needs to be implemented in the city but should be practiced in the campus area (Marzuki 2011). Ease of transport of the area played a role in something that is important for mobility of the road users to travel from one location to the other destinations (Nurdden et al. 2007). Bicycle is something that can be owned and suitable for campus lifestyle (Bonham \& Koth 2010). It is a good alternative in leading us for a more sustainable transportation system, reliable and safe for the environment. In UKM however, cycling mode of transport is not well received due to several factors such as hilly terrain, weather condition and lack of cycling infrastructure. This study was conducted to find the probability of students who are willing to shift to cycling mode of transport within the campus area to commute.

Students are not fond using bicycle in campus over factors such as the topography of the earth, the weather conditions and bicycle facilities which received less attention in the campus (Moudon et al. 2005). Besides, students only tend to cycle for physical and leisure activities. However, for the purpose of going to lecture or perform daily routine, the students are interested in using motorized vehicles such as buses, trains, and motorcycle (Wardman et al. 2007). Students in campus are more likely to choose a motorized vehicle compared to active transportation. 
Motorized vehicles can cause air pollution and noise pollution. Besides, it may leads to higher traffic congestion around the campus and may cause higher parking demand among the staffs, lecturers and students as well. Hence, another mode of transport should be suggested to be the alternative for mobility around the campus.

\section{LITERATURE REVIEW}

Monthly income, gender and age also affect the probability rate of bicycle modal shift in Flanders (Vandenbulcke et al. 2011). Lower monthly income, lower rate of women vacancies and younger age (below 45) are some factors that will grant higher bicycle modal shift probability. Having one or more children (age between 0-5) in household also might decrease the probability to travel to work by using bicycle. Having higher education qualification level is also an important factor in the study of bicycle modal shift, especially in south Brussels. Commuters who have higher education that lives in Wallonia and having higher wages will tend to afford to own cars and use them to make a farther travel working distance. They will less likely to use bicycle in daily routine.

Campaigns and civil educational programmes may help in handling several socio economic issues. Some civil and private companies must try to encourage alternatives to decrease usage of motorized transport to decrease traffic congestions and car parks demand. Flat plains and non hilly terrains, well facilities and lower risk exposre to accidents can encourage people to use bicycle (Spencer et al. 2013). However, traffic congestions (in city streets) is not a significant effect in Flanders, eventhough it is assumed to be a factor that to make people dislike using bicycle in Wallonia and Brussels.

In Flanders, highly visibility path and good level of cycling infrastructure play an important role in encouraging people to cyclist. This is to provide safety and prevent theft. This may help reducing the number of motorized vehicle in certain heavily congested roads. In other research, weather conditions also affect the bicyle modal shift (Nankervis 1999). Nankervis found out that three important elements that needs to be highlighted, which are the wind speed, rate of rainfalls and thermal condition.

\section{METHODOLOGY}

The study begins with conducting literature review, collecting data from authorities, distributing and collecting survey questionnaires. 170 questionnaires were given out to the students who lived in campus. The data obtained were then analyzed using SPSS software to identify the factors that affect student's choice of transport in the campus. After that, a bicycle shift model was developed using linear regression logistic model.

Based on the literature review, there are several factors that contributed to road accidents, such as topography, weather condition, travelling distance, parking facilities, visibilities and commute time (Flynn et al. 2012). Survey questionnaires were distributed to 170 respondents of UKM Bangi campus on April 2013. The surveys were then aggregated and analyzed using SPSS (Blaikie 2003).

The linear regression logistic model was then developed using Microsoft Excel with aid from SPSS (Bryman \& Cramer 2005). Base on the model, the probability of respondent to shift can be determined. From the factors studied, bicycle shift model was developed to determine the probability of student to shift to bicycle if alternatives were provided.

\section{RESULT AND DISCUSSION}

$$
\text { SURVEY DATA ANALYSIS }
$$

The sample of this survey is 170 respondents. In the survey, $48.2 \%$ is male while $51.8 \%$ is female. The survey question is conducted in the main campus of UKM Bangi, which is around Pusanika area, resident colleges, faculties and cafeteria.

\section{REVEALED AND STATED PREFERENCES STUDY}

This study was conducted based on revealed and stated preferences study. Revealed preferences study (RP) can be explained on what mode of transport the respondent is currently use inside the campus. Respondents need to answer several questions regarding on the current situation and problems they face every day which contribute to the choice of transport. Meanwhile stated preferences study (SP) is several alternatives and improvements to their selection of mode transport.

The survey is conducted on several factors that affecting the respondent choice in using bicycle such as topography, weather, safety, security, visibility and commuting time aspect. In Figure 1 shows the result of survey from RP questions which asking the respondents what is problem faced if using bicycle around the campus. For hilly factors, 76.5\% respondents agreed that the hilly path around the campus is the main factor why they did not prefer to use bicycle to commute. $79.4 \%$ of the respondents also agree that the uncertain weather is affecting them not to use bicycle but use cars or buses instead.

In Figure 2, it shows the results of SP survey question which is asking if there are alternatives and changes, will the respondents shifts to bicycle mode in the campus to commute? $87.6 \%$ of the respondents agree they would shift to bicycle if the path is not hilly. $91.2 \%$ of them also agree if the lane for bicycle is covered so they would be covered from rains and hot sun rays. 85.3\% agree if the travel distance is short and acceptable.

From Figure 1 and Figure 2, we can observe the current situation and the ideal condition that might make the respondents want to shift to bicycle. From the RP questions given, respondent shows that they agree to the factor of hilly terrain, uncertain weather, far distance, accident risks, theft, low visibility, and time which makes them use motorized transport as their main choice. But after given SP questions, 


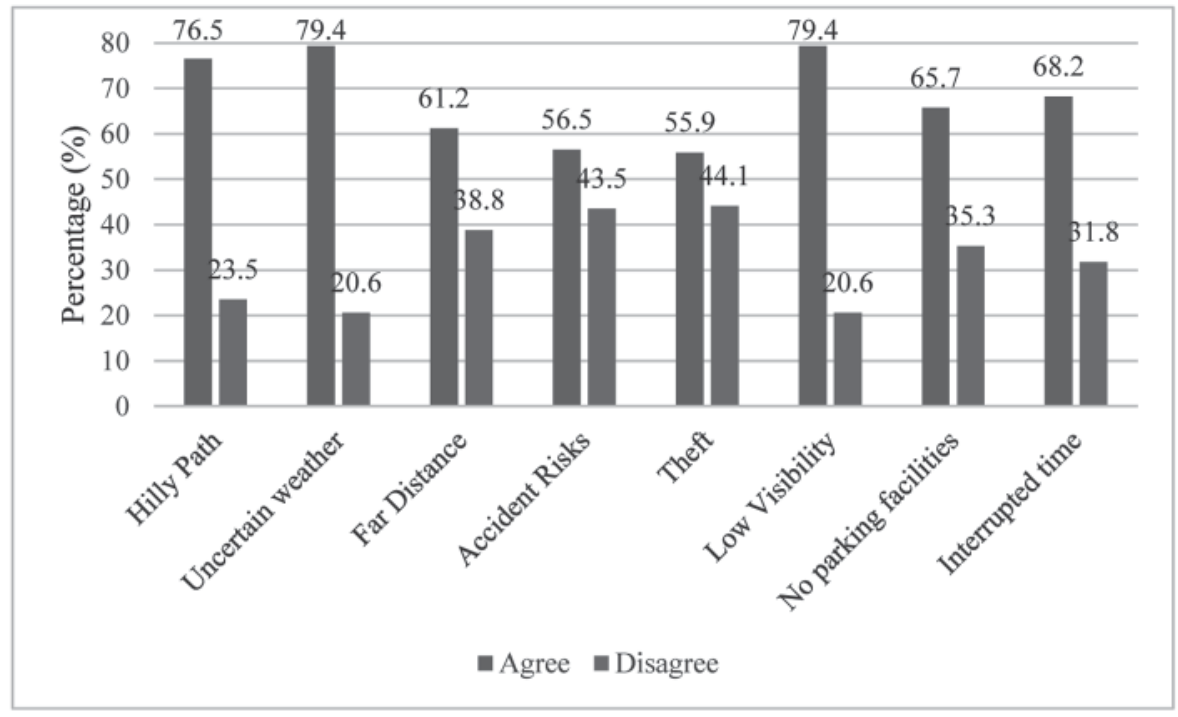

FIGURE 1. RP survey questions

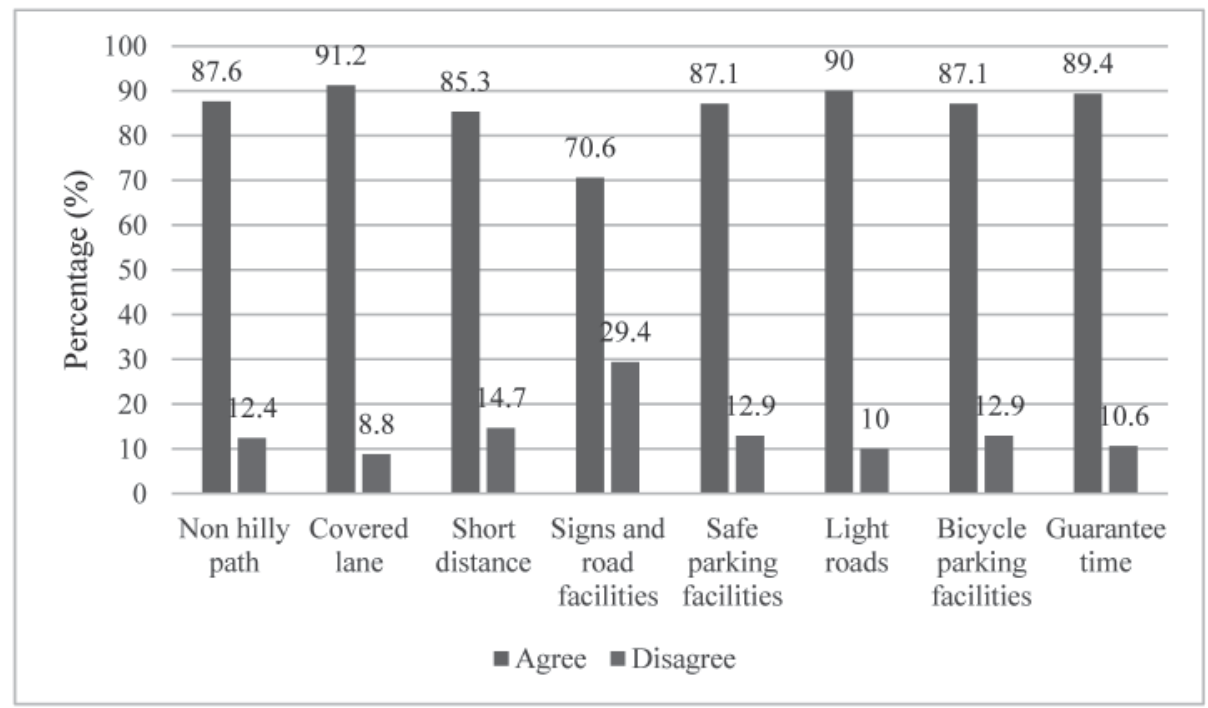

FIGURE 2. SP survey questions

they may tend to shift to bicycle if improvements and alternatives provided.

\section{BICYCLE SHIFT MODEL}

In this study, a bicycle shift model has been developed to predict the probability of respondents to shift from using owned motorized transport or public motorized transport to bicycle. The model was developed using data from 170 respondents earlier. The data was analyzed and a linear regression was developed for the travel distance of non-hilly path and the travel distance of covered lane. The main purpose of the model is to predict the probability of respondents to shift to bicycle mode transport.

The respondents were asked to select the travel cycling distance that they are willing to go through if the path is not hilly. The proposed distance is less than 200 meters to over 1000 meters. Based on the results obtained, a linear regression analysis was conducted on the percentage of the respondent to shift from owned transports to bicycle mode transport. Table 1 shows the data in developing the shift model based on the travel distance of non-hilly tracks or paths. 
TABLE 1. Data of bicycle shift model based on the travel distance of non-hilly tracks

\begin{tabular}{cccccc}
\hline Distance $(\mathrm{m})$ & \% of shifting & $\mathrm{P}_{\text {experimental }}$ & $\ln [(1-\mathrm{P}) / \mathrm{P}]$ & $\mathrm{P}_{\text {model }}$ & $\mathrm{Y}_{\text {model }}$ \\
\hline 200 & 21.76 & 0.2176 & 1.2794 & 0.2249 & 1.2375 \\
400 & 35.88 & 0.3588 & 0.5805 & 0.3496 & 0.6206 \\
600 & 50.59 & 0.5059 & -0.0235 & 0.4991 & 0.0037 \\
800 & 64.71 & 0.6471 & -0.6061 & 0.6487 & -0.6132 \\
1000 & 77.06 & 0.7706 & -1.2116 & 0.7738 & -1.2300 \\
\hline
\end{tabular}

The $\mathrm{P}_{\text {experimental }}$ is the actual probability calculated from the result of the questionnaires while the $\mathrm{P}_{\text {model }}$ is obtained from the regression analysis model using Microsoft Excel data.

From Microsoft Excel, we obtained:

$$
\begin{aligned}
& \alpha=0.003084372 \\
& C=\mathrm{e}^{1.854343733}=6.3875
\end{aligned}
$$

So, the estimated bicycle shift model based on non-hilly tracks is:

$$
\begin{aligned}
& P_{1}=\frac{1}{1+6.3875 e^{(-0.003084372 j)}} \\
& j=\text { Travel distance }(\mathrm{m})
\end{aligned}
$$

Figure 3 shows that there is not much differences observed between the experimental probability $\left(\mathrm{P}_{\text {experimental }}\right)$ with the logistic model probability $\left(\mathrm{P}_{\text {model }}\right)$ obtained. This proves that the values obtained are suitable for this study.

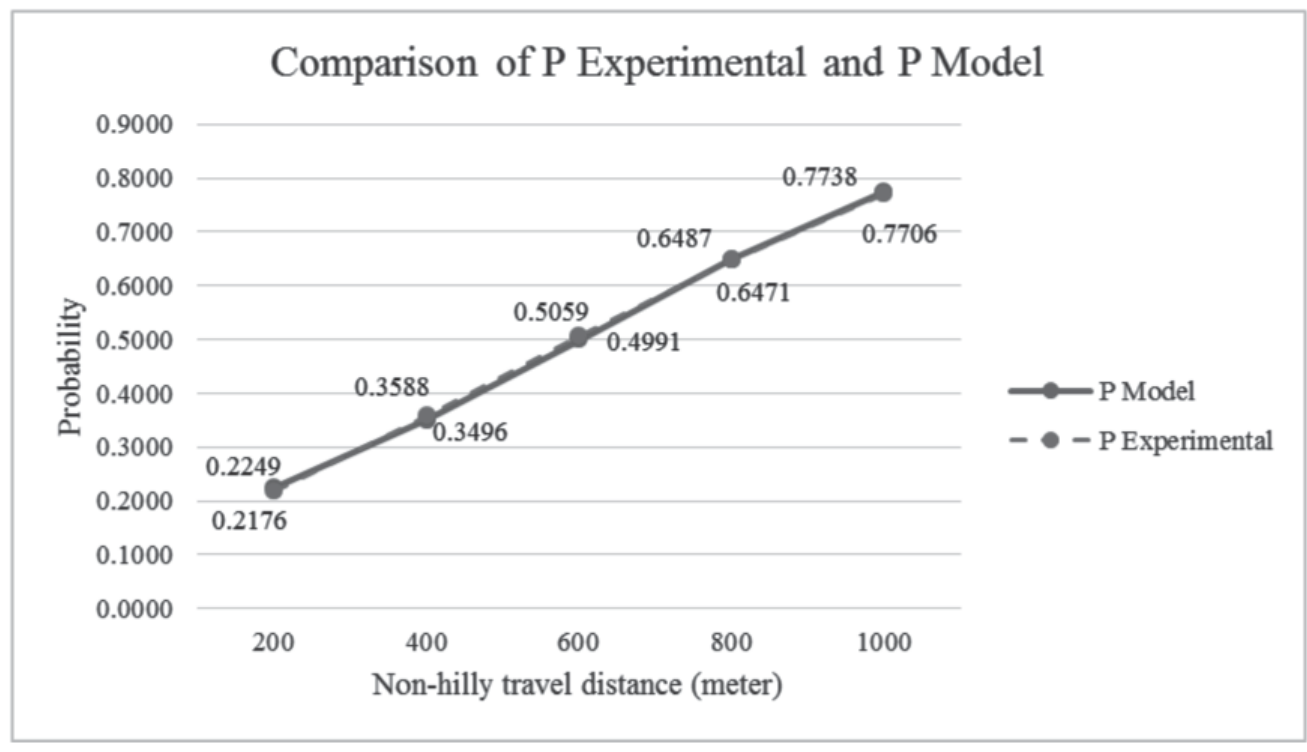

FIGURE 3. Comparison of P Experimental and P Model based on non-hilly travel distance

Based on Table 2, the $p$-value is 0.000017238 where it is accepted to be significant $(p<0.05)$.

TABLE 2. Regression analysis for variable 1 (V1)

\begin{tabular}{lcccc}
\hline & Coefficient & Standard Error & t Stat & p-value \\
\hline Intercept & 1.854343733 & 0.04062311 & 45.64750736 & $2.31 \mathrm{E}-05$ \\
X Variable 1 & -0.003084372 & $6.12416 \mathrm{E}-05$ & -50.36396216 & $1.72 \mathrm{E}-05$ \\
\hline
\end{tabular}

For the proposed of non-hilly route ranged as low as 200 meters, a total of $22.49 \%$ of the respondents are willing to shift to cycling while $77.51 \%$ are not willing to shift.
The travel distance of more than 1000 meters, $77.38 \%$ of respondents are willing to shift while the remaining $22.62 \%$ are not willing to switch to cycling. There are findings that agreeable with study by Jalalkamali et al. (2012). Therefore, it can be concluded here that, if the terrain is less steep and flat, the students will be more likely to cycle in campus.

Weather condition is the second factor that affects the mode transport choice in the campus. The respondents are unable to commute if rain falls heavily and thus affecting daily schedule for lectures. Based on this factor, a bicycle shift model is developed based on the travel distance if covered lane facility was built. The study conducted to determine the travel distance using bicycle starting from 200 meter to 


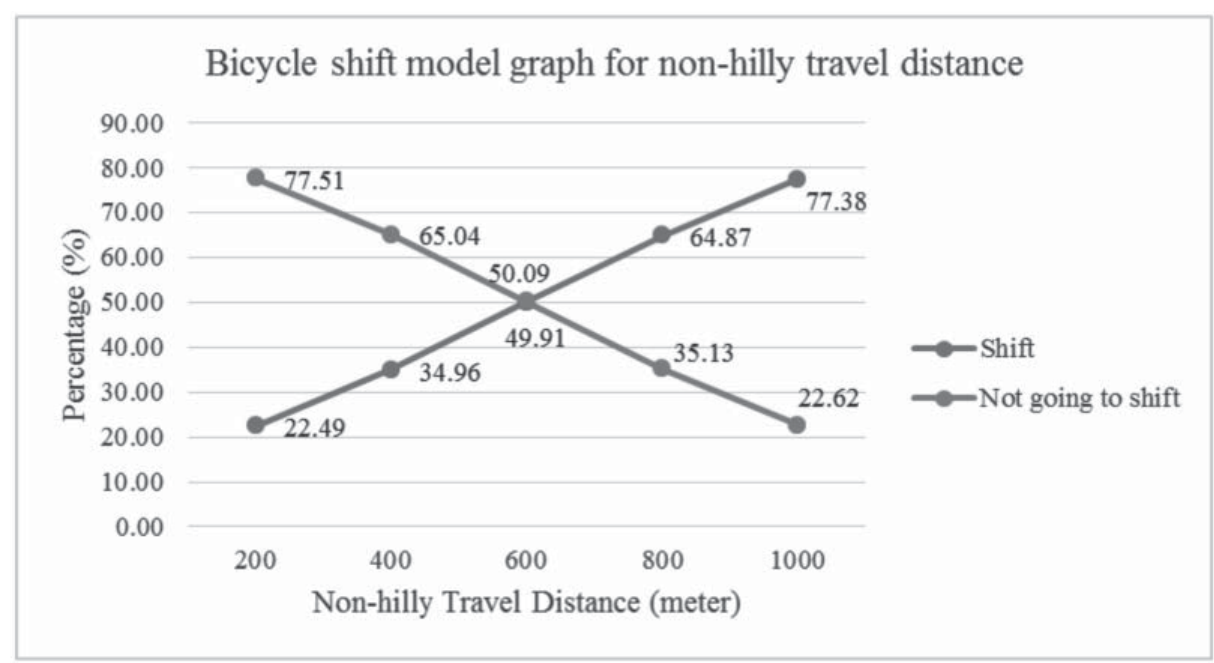

FIGURE 4. Graph of bicycle modal shift and not going to shift percentage based on non-hilly travel distance

more than 1000 meter if there is covered lane provided and the data was shown on Table 3.

From Microsoft Excel, we obtained:

$$
\begin{aligned}
& \alpha=0.003603724 \\
& C=\mathrm{e}^{2.564258647}=12.991
\end{aligned}
$$

So the probability for bicycle shift model based on covered lane provided is:

$$
\begin{array}{r}
P_{2}=\frac{1}{1+12.991 e^{(-0.003603724 j)}} \\
j \quad=\text { Travel distance }(\mathrm{m})
\end{array}
$$

TABLE 3. Data of bicycle shift model based on the travel distance $\mathrm{f}$ covered lane provided

\begin{tabular}{cccccc}
\hline Distance $(\mathrm{m})$ & \% of shifting & $\mathrm{P}_{\text {experimental }}$ & $\ln [(1-\mathrm{P}) / \mathrm{P}]$ & $\mathrm{P}_{\text {model }}$ & $\mathrm{Y}_{\text {model }}$ \\
\hline 200 & 12.94 & 0.1294 & 1.9062 & 0.1366 & 1.8435 \\
400 & 24.71 & 0.2471 & 1.1144 & 0.2455 & 1.1228 \\
600 & 42.35 & 0.4235 & 0.3083 & 0.4008 & 0.4020 \\
800 & 58.82 & 0.5882 & -0.3567 & 0.5790 & -0.3187 \\
1000 & 72.35 & 0.7235 & -0.9620 & 0.7387 & -1.0395 \\
\hline
\end{tabular}

Figure 5 shows that there is only a small difference between the experimental probabilities $\left(\mathrm{P}_{\text {experimental }}\right)$ with the logistic model probabilities $\left(\mathrm{P}_{\text {model }}\right)$. This proves that the values are suitable for the use of the study.

Based on Table 4, the linear regression developed has $p$-value of 0.000102558 where it can be accepted to be significant $(p<0.05)$.

Figure 6 shows the bicycle modal shift based on the travel distance if covered lane is provided.

A total of $13.66 \%$ of the respondents are willing to shift to bicycle if covered lane is provided at a distance of 200 meters. It increased to $73.87 \%$ at a distance of 1000 meters. At a distance of 710 meters, there is an interception of values between the percentage of users who are willing and not willing to shift to bicycle. From the values obtained, it can be concluded that if the walkway is provided, consumers will be more willing to cycle within farther travel distance than a shorter distance (Mukherjee 2011).
From both bicycle modal shifts, we can observed the suitable distance of cycling is about 598 to 710 meters as they are the intersecting values between those who are willing to shift to bicycle. It is suggested that the students inside campus are placed within the radius to make bicycle commuting more efficient and optimized.

\section{CONCLUSION}

Topography and weather condition is the main factor that affecting the choice of student on using bicycle (Shannon et al. 2006). In this study, if the path of travel is not hilly and if there is covered lane provided, the probability of people to shift to bicycle mode transport will increase. Hence, this will lead to a better environment and sustainable transportation system in the campus (Norzalwi \& Amiruddin 2011). After conducting this study, there are several improvements that can 


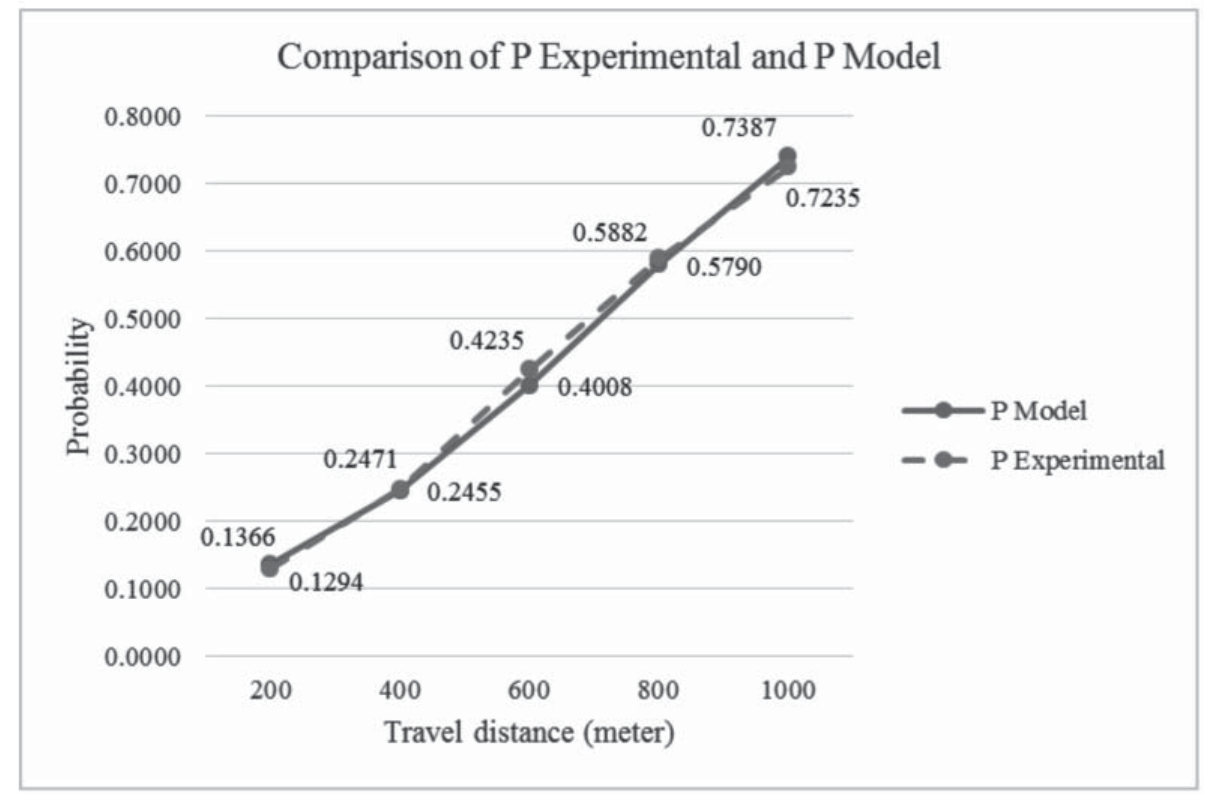

FIGURE 5. Comparison of $\mathrm{P}_{\text {Experimental }}$ and $\mathrm{P}_{\text {Model }}$ based on travel distance if covered lane is provided

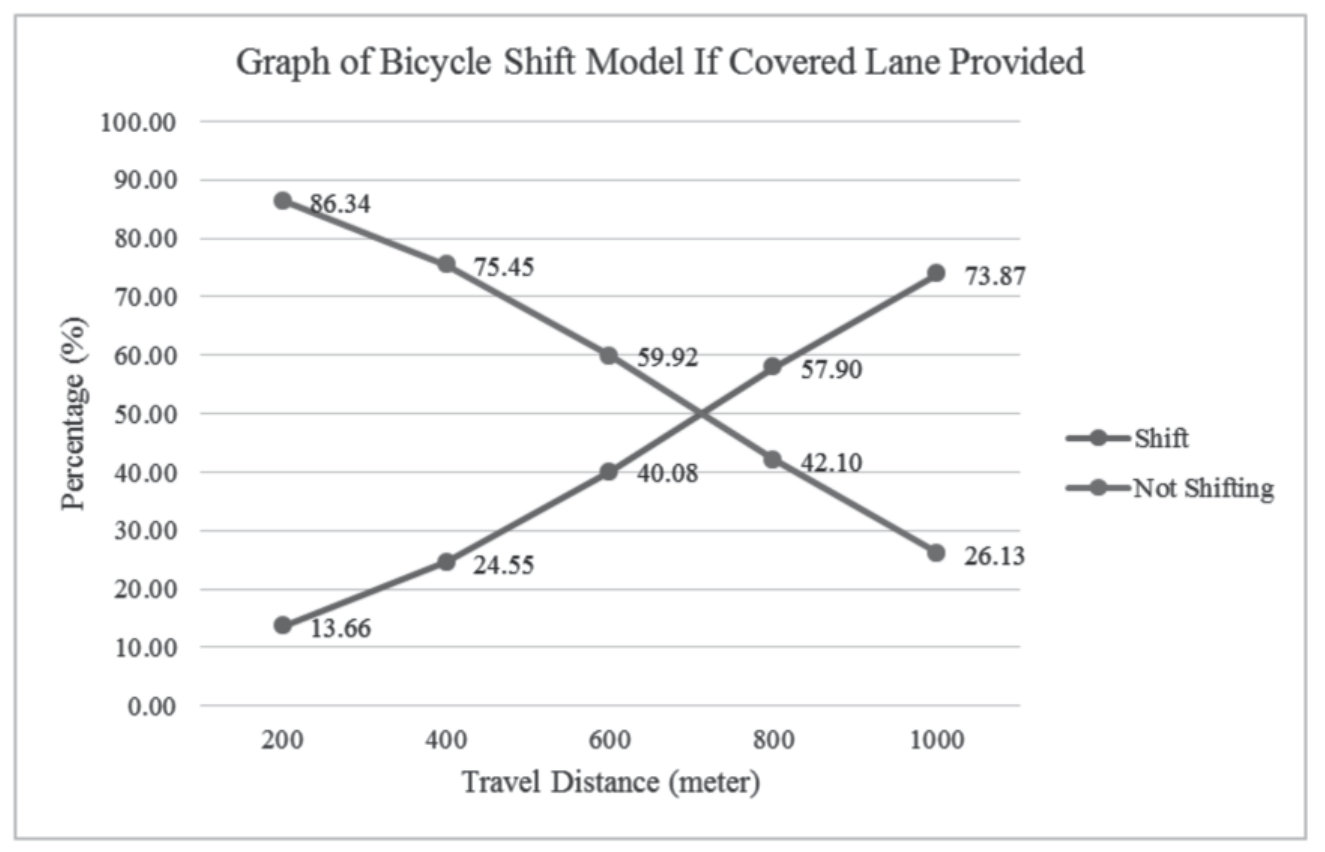

FIGURE 6. Graph of bicycle modal shift and not going to shift percentage based on travel distance if covered lane is provided

TABLE 4. Regression analysis for variable 2 (V2)

\begin{tabular}{lcccc}
\hline & Coefficient & Standard Error & t Stat & p-value \\
\hline Intercept & 2.564258647 & 0.086096444 & 29.78356037 & $8.31 \mathrm{E}-05$ \\
X Variable 2 & -0.003603724 & 0.000129795 & -27.76468105 & 0.000103
\end{tabular}

be done to enhance the usage of bicycle inside the campus. We find out that students are not willing to use active transport within about 600 meters from the interception of data from Figure 4. Hence, we might able to place the students within this radius from residential college to the faculties. This can encourage students to use bicycle as the commute distance is reasonable. 
ACKNOWLEDGEMENT

The author would like to acknowledge the Sustainable Urban Transport Research Centre (SUTRA), Faculty of Engineering and Built Environment, Universiti Kebangsaan Malaysia (UKM), for providing research facilities.

\section{REFERENCES}

Blaikie, N. 2003. Analyzing quantitative data: from description to explaination. Applied Statistics: 96-105. Sage Publications.

Bonham, J. \& Koth, B. 2010. Universities and the cycling culture. Transportation Research Part D: Transport and Environment 15(2): 94-102.

Bryman, A. \& Cramer, D. 2005. Quantitative data analysis with SPSS 12 and 13: 201-236. Routledge Taylor\& Francis Group.

Flynn, B. S., Dana, G. S., Sears, J. \& Aultman-Hall, L. 2012. Weather factor impacts on commuting to work by bicycle. Preventive Medicine 54(2): 122-4.

Jalalkamali, N., Mohammad, F. \& Ghraei, N. 2012. The cycling potentials of Malaysian students in UiTM campus. Procedia - Social and Behavioral Sciences 50(7): 941-949.

Marzuki, M. 2011. Memperkasa perancangan laluan jalan kaki untuk pembangunan lestari kampus: Kajian di UPSI: 1-14.

Moudon, A. V., Lee, C., Cheadle, A. D., Collier, C. W., Johnson, D., Schmid, T. L. \& Weather, R. D. 2005. Cycling and the built environment, a US perspective. Transportation Research Part D: Transport and Environment 10(3): 245-261.

Mukherjee, A. 2011. Harmonization and enforcement of sidewalk cycling by laws in the city of Toronto. Toronto.

Nankervis, M. 1999. The effect of weather and climate on bicycle commuting: 33.

Nkurunziza, A., Zuidgeest, M., Brussel, M. \& Van Maarseveen, M. 2012. Examining the potential for modal change: Motivators and barriers for bicycle commuting in Dar-es-Salaam. Transport Policy 24: 249-259.
Norzalwi, N. \& Amiruddin, I. 2011. Public approach towards sustainable transportation in UKM's Campus. Australian Journal of Basic Applied Sciences 5(5): 1332-1337.

Nurdden, A., Rahmat, R. A. O. K. \& Ismail, A. 2007. Efect of transportation policies on modal shift from private car to public transportation in Malaysia. Journal of Applied Science 7: 1013-1018.

Shannon, T., Giles-Corti, B., Pikora, T., Bulsara, M., Shilton, T. \& Bull, F. 2006. Active commuting in a university setting: Assessing commuting habits and potential for modal change. Transport Policy 13(3): 240-253.

Spencer, P., Watts, R., Vivanco, L. \& Flynn, B. 2013. The effect of environmental factors on bicycle commuters in Vermont: Influences of a northern climate. Journal of Transport Geography 31: 11-17.

Vandenbulcke, G., Dujardin, C., Thomas, I., Geus B. De, Degraeuwe, B., Meeusen, R. \& Panis, L. I. 2011. Cycle commuting in Belgium: Spatial determinants and recycling strategies. Transportation Research Part A: Policy and Practice 45(2): 118-137.

Wardman, M., Tight, M. \& Page, M. 2007. Factors influencing the propensity to cycle to work. Transportation Research Part A: Policy and Practice 41(4): 339-350.

Amiruddin Ismail \& Shazrizil Zakaria* ${ }^{1}$ Sustainable Urban Transport Research Centre (SUTRA) Universiti Kebangsaan Malaysia 43600 UKM Bangi, Selangor D.E. Malaysia

\section{Shazrizil Zakaria}

Department of Civil and Structural Engineering Faculty of Engineering and Built Environment Universiti Kebangsaan Malaysia 43600 UKM Bangi, Selangor D.E. Malaysia

*Corresponding author; email: shazrizil@yahoo.com.my

Received date: $13^{\text {th }}$ July 2014

Accepted date: $20^{\text {th }}$ October 2014 
